\title{
JPEB
}

Jurnal Penelitian Ekonomi dan Bisnis, 2 (2), 2017, Hal : 92 - 100

http://www.jpeb.dinus.ac.id

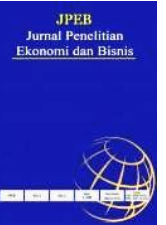

\section{PENGARUH KONFLIK PERAN DAN AMBIGUITAS PERAN TERHADAP STRES KERJA DAN KINERJA PEGAWAI DINAS PENERANGAN JALAN DAN PENGELOLAAN REKLAME KOTA SEMARANG}

\author{
Agus Joko Triyono ${ }^{1}$ dan Agus Prayitno ${ }^{2 *}$ \\ Magister Manajemen, Universitas Dian Nuswantoro Semarang \\ Jalan Imam Bonjol No. 207 Semarang 50131, Indonesia \\ *Corresponding Author: agus.prayitno@dsn.dinus.ac.id
}

Diterima: April 2017; Direvisi: Juli 2017; Dipublikasikan: September 2017

\begin{abstract}
The purpose of this study was to analyze the effect of role conflict and role ambiguity on work stres and its impact on the performance of employees of the Street Lighting and Advertising Management Agency (PJPR) Semarang. Respondents of this study were all PJPR Semarang employees, amounting to 111 people. Data analysis techniques used structural equation models. The results of this study conclude that: role conflict and role ambiguity have a positive effect on work stres. Role conflict has a higher influence than the influence of role ambiguity. This study also concluded that role conflict, role ambiguity and work stres negatively affected employee performance. The biggest role ambiguity in reducing employee performance. Role conflict has a greater indirect effect, while role ambiguity has a greater direct influence. So that both role conflict and role ambiguity need to be considered in a balanced manner.
\end{abstract}

Keywords : Role Conflict; Role Ambiguity; Work Stres; Employee Performance

\begin{abstract}
ABSTRAK
Tujuan penelitian ini adalah menganalisis pengaruh konflik peran dan ambiguitas peran terhadap stres kerja serta dampaknya terhadap kinerja pegawai Badan Penerangan Jalan dan Pengelolaan Reklame (PJPR) Semarang. Responden penelitian ini adalah seluruh pegawai PJPR Semarang yang berjumlah 111 orang, Teknik analisis data menggunakan model persamaan struktural. Hasil penelitian ini menyimpulkan bahwa: konflik peran dan ambiguitas peran berpengaruh positif terhadap stres kerja. Konflik peran memiliki pengaruh lebih tinggi dibanding pengaruh ambiguitas peran. Penelitian ini juga menyimpulkan konflik peran, ambiguitas peran dan stres kerja berpengaruh negatif terhadap kinerja karyawan. Ambiguitas peran paling besar dalam menurunkan kinerja karyawan. Konflik peran memiliki pengaruh tidak langsung lebih besar, sedangkan ambiguitas peran memiliki pengaruh langsung lebih besar. Sehingga baik konflik peran maupun ambiguitas peran perlu diperhatikan secara berimbang.
\end{abstract}

Kata kunci : Konflik Peran; Ambiguitas Peran; Stres Kerja; Kinerja Karyawan 


\section{PENDAHULUAN}

Kinerja pegawai didefinisikan sebagai kemampuan pegawai dalam melakukan sesuatu keahlian tertentu, dan dengan kinerja akan diketahui seberapa jauh kemampuan pegawai dalam melaksanakan tugas yang dibebankan kepadanya (Sinambela, 2012). Tingkat kemampuan pegawai dalam menyelesaikan tugasnya akan memberi sumbangan terhadap kinerja organisasi, baik pegawa pada organisasi swasta maupun pegawai pada organisasi publik atau pegawai negeri sipil (PNS). Kinerja yang ditunjukkan oleh PNS di suatu daerah merupakan salah satu bentuk cerminan kinerja suatu organisasi pemerintah daerah, sehingga pemerintah daerah harus dapat mengukur dan mengevaluasi kinerja para PNS di organisasi atau lingkungan kerjanya. Para pegawai dituntut untuk dapat bekerja lebih maksimal dan mampu menyelesaikannya dengan batas waktu yang telah ditentukan.

Beban kerja yang banyak menyebabkan benturan-benturan atau tekanan-tekanan yang terjadi pada dirinya yang dapat menimbulkan stres bagi pegawai sehingga berdampak pada penurunan kinerja pegawai (Kirkcaldy et. al., 2000). Mangkunegara (2012), mengemukakan bahwa stres kerja adalah tekanan yang dirasakan pegawai dalam menghadapi pekerjaan.

Berbagai faktor stres kerja telah menjadi kajian para peneliti, yaitu konflik peran (Usman A., et al. 2011; Safaria et al. 2011); Quarat-ul-ain, dkk. 2012; Celik. 2013), Ambiguitas peran (Nurqamar dkk. 2014). Ditinjau dari kesimpulan penelitian juga terdapat kontradiksi hasil penelitian. Usman A., et al.(2011) konflik peran dan ambiguitas peran berpengaruh positif terhadap stres kerja. Hasil penelitian ini didukung oleh Celik(2013). Safaria et al. (2011) dan Rosita (2013) menyimpulkan konflik peran dan ambiguitas peran tidak berpengaruh terhadap stres kerja. Nurqamar(2014) Konflik peran berpengaruh pada stres kerja sedangkan ambiguitas peran berpengaruh negatif terhadap stres kerja.

Berdasarkan perbedaan-perbedaan hasi penelitian di atas, maka pertanyaan penelitian yang dajukan adalah:1) bagaimana pengaruh konflik peran dan ambiguitas peran terhadap stres kerja ? 2) bagaimana konflik peran, ambiguitas peran dan stres kerja terhadap kinerja pegawai?

\section{TINJAUAN PUSTAKA \\ Kinerja Pegawai}

Sinambela (2012), kinerja adalah kemampuan pegawai dalam melakukan sesuatu keahlian atau tugas tertentu yang dibebankan. Terdapat tiga faktor yang dapat mempengaruhi kinerja yaitu faktor individu, psikologis, dan faktor Organisasi. Sutrisno (2011 : 172), mengemukakan empat aspek dari kinerja, yaitu : kualitas pekerjaan, kuantitas pekerjaan yang dihasilakan, ketepatan waktu menyelesaikan dan kerja sama. Faktor yang dapat mempebgaruhi kinerja pegawai adalah stres kerja (Saina, 2013; Quarat-ul-ain et al., 2013), konflik peran (Safaria dkk. 2011), ambiguitas peran (Safaria dkk., 2011; Celik, 2013).

\section{Stress Kerja}

Handoko (2010), stress adalah suatu kondisi ketegangan yang mempengaruhi emosi, proses berfikir dan kondisi seseorang. Menurut Rivai \& Sagala (2009), stress adalah kondisi ketegangan yang menciptakan adanya ketidakseimbangan fisik dan psikis, yang mempengaruhi emosi, proses berfikir, dan kondisi seorang. Gejala stress ditempat kerja menurut Rivai \& Mulyadi (2011), yaitu: kepuasan kerja rendah, kinerja yang menurun, semangat dan energy menjadi hilang, komunikasi tidak lancar, pengambilan keputusan jelek, kreativitas dan inovasi kurang. tidak produktif.

\section{Konflik Peran}

Robbins dan Timothy (2008), suatu kondisi saling memiliki persepsi bahwa pihak lain akan atau telah mepengaruhi secara negatif. Menurut Luthans (2011), seseorang akan mengalami konflik peran jika ia memiliki dua peran atau lebih yang harus dijalankan pada waktu yang bersamaan. Kreitner \& Kinicki (2014) mengatakan bahwa konflik peran adalah para pegawai memiliki pengharapan yang saling bertentangan atau tidak konsisten. Konflik peran muncul ketika seseorang menerima pesan yang tidak sebanding berkenaan dengan perilaku peran yang sesuai (Ivancevich, 2007). Menurut Munandar (2008), indikasi konflik peran timbul jika pegawai mengalami (1) pertentangan antara tugas-tugas yang harus dilakukan dengan tanggung jawab yang dimiliki, (2) tugas yang harus dilakukan merasa 
Agus Joko Triyono dan Agus Prayitno : Pengaruh Konflik Peran Dan Ambiguitas Peran Terhadap Stres Kerja Dan Kinerja Pegawai Dinas Penerangan Jalan Dan Pengelolaan Reklame Kota Semarang

bukan merupakan bagian dari pekerjaannya, (3) tuntutan-tuntutan yang bertentangan dari atasan, rekan, bawahannya, atau orang lain yang dinilai penting bagi dirinya, dan 4) pertentangan dengan nilai-nilai dan keyakinan pribadinya sewaktu melakukan tugas pekerjaannya.

\section{Ambiguitas Peran}

Menurut Kreitner \& Kinicki (2014), ambiguitas peran adalah pengharapan orang lain yang tidak diketahui. Kurangnya informasi atau karena tidak adanya informasi sama sekali atau informasinya tidak disampaikan akan muncul ambiguitas peran (Cahyono, 2008). Ketika tidak ada kepastian tentang definisi kerja dan apa yang diharapkan dari pekerjaannya maka akan timbul ambiguitas peran (Rivai dan Mulyadi, 2011). Nimran (2004: 100), seseorang mengalami ambiguitas peran memiliki ciri ciri (1) tujuan peran tidak jelas, (2) tidak jelas kepada siapa harus bertanggung jawab. (3) tidak memiliki wewenang yang cukup untuk melaksanakan tanggung jawab, (4) tidak mengerti sepenuhnya apa yang diharapkan. (5) tidak memahami peranan pekerjaannya dalam mencapai tujuan organisasi secara keseluruhan.

\section{Konflik Peran Dan Stres Kerja}

Penelitian yang dilakukan Usman, dkk(2011) membuktikana bahwa konflik peran memiliki pengaruh positif terhadap stres kerja. Jika pegawai merasa terdapat pertentangan antara tugas-tugas yang harus ia lakukan dengan tanggung jawab yang dimiliki, tugas yang dilakukan bukan pekerjaannya, bertentangan dengan tuntutan atasan dan rekan kerjanya, dan bertentangan dengan nilai-nilai yang diyakini maka akan stres membuat seorang pegawai. Sejalan dengan hasil penelitian Quarat-ul-ain, dkk (2012) dan Nurqamar, dkk (2014) yang menyimpulkan konflik peran berpengaruh positif signifikan terhadap stres kerja. Semakin besar konflik peran seorang pegawai akan menjadi mudah stres.

$\mathrm{H}_{1}$ : Konflik peran berpengaruh positif terhadap Stres kerja

\section{Ambiguitas Peran Dan Stres Kerja}

Usman dkk (2011) membuktikan bahwa ambiguitas peran berpengaruh positif signifikan terhadap stres kerja. Quarat-ul-ain, dkk (2012) juga menyimpulkan bahwa ambiguitas peran yang meningkat mengakibatkan pegawai semakin stres. Jika pegawai dituntut bekerja secara baik, tetapi tidak diikuti dengan kejelasan peran, kejelasan pertanggungjawaban, kewewenangan yang cukup, dan pemahaman peranan pekerjaan dalam mencapai tujuan organisasi maka pegawai memiliki kecenderungan menjadi stres.

$\mathrm{H}_{2}$ : Ambiguitas peran berpengaruh positif terhadap Stres kerja.

\section{Konflik Peran, Ambiguitas Peran, Stres Kerja Dan Kinerja Pegawai}

Celik (2013) menemukan bukti bahwa konflik peran berpengaruh signifikan terhadap kinerja pegawai. Meningkatnya konflik peran yang dialami oleh seorang pegawai berakibat negatif terhadap kinerjanya karena akan lebih mencurahkan energinya untuk mengatasi konflik peran tersebut daripada menyelesaikan tugas atau pekerjaannya dengan baik. Sejalan dengan penelitian Penelitian Saina (2013), dan Patria (2016) yang menyimpulkan bahwa konflik peran berpengaruh negatif terhadap kinerja.

$\mathrm{H}_{3}$ : Konflik peran berpengaruh negatif terhadap Kinerja pegawai.

Ambiguitas peran berpengaruh siginifikan dan negatif terhadap kinerja pegawai (Nurqamar, dkk., 2014; Celik, 2013) menunjukkan hasil bahwa ambiguitas peran memiliki pengaruh negatif terhadap kinerja karyawan. Ketika pegawai mengalami ambiguitas peran, akan tidak mengetahui secara jelas bagaimana melaksanakan pekerjaan secara efektif, maka 
pegawai akan bekerja tidak efisien dan tidak terarah, sehingga kualitas dan kuantitas pekerjaannya menurun, serta cenderung tidak menyelesaikan tepat waktu.

$\mathrm{H}_{4}$ : Ambiguitas peran berpengaruh negatif terhadap Kinerja pegawai.

Stres kerja berpengaruh negatif terhadap kinerja pegawai (Saina, 2013 dan Nurqamar, dkk., 2014). Menurut Rivai, H.V. \& Sagala, E.J. (2009), suatu kondisi ketegangan menciptakan ketidakseimbangan fisik dan psikis yang dapat mempengaruhi emosi, proses berfikir, dan kondisi seorang karyawan. Pegawai yang stres memiliki emosi tidak stabil, proses berpikir yang tidak jernih dan kesehatan terganggu. Dampaknya adalah kinerja pegawai menurun.

$\mathrm{H}_{5}$ : Stres kerja berpengaruh negatif terhadap Kinerja pegawai

\section{METODE PENELITIAN \\ Pengumpulan Data}

Penelitian dilakukan dengan pengumpulan data primer melalui penyebaran kuesioner kepada 111 pegawai tetap di Dinas PJPR Semarang. Jenis data yang digunakan adalah data kualitatif yang meliputi persepsi pegawai tentang konflik peran, ambiguitas peran, dan stres kerja masing-masing diukur dengan 5 indikator dan kinerja pegawai diukur dengan 4 indikator. Daftar keseluruhan indikator seperti yang tercantum pada tabell. Skala yang digunakan adalah skala likert 1 (sangat tidak setuju) sampai dengan 7 (sangat setuju), dengan tiga kategori yaitu 1-3 rendah, 3-5 sedang dan 5-7 tinggi. Analisis data menggunakan Structual Equation Model.

Tabel 1. Definisi Operasional Dan Indikator Variabel

\begin{tabular}{cl}
\hline \multicolumn{1}{c}{ Variabel } & \multicolumn{1}{c}{ Definisi Operasional } \\
\hline Konflik Peran & $\begin{array}{l}\text { Konflik peran adalah } \\
\text { pertentangan atau perbedaan } \\
\text { sudut pandang, gagasan dan } \\
\text { pendapat yang dirasakan } \\
\text { pegawai tentang tugas, } \\
\text { tanggungjawab, wewenang, } \\
\text { rekan kerja, nilai-nilai pribadi, } \\
\text { dan keyakinan. }\end{array}$ \\
Ambiguitas peran sebagai \\
Ambiguitas \\
Peran & yang jelas mengenai \\
& tanggungjawab dan harapan \\
dari suatu jabatan, yang \\
dibutuhkan bagi pemegang \\
peran untuk dapat berkinerja \\
dengan memadai sesuai peran \\
yang dipegangnya.
\end{tabular}

Stres Kerja Stres kerja merupakan kondisi psikis dan fisik pegawai yang meliputi semangat kerja Indikator

1. Ketidaksesuaian tugas dengan tanggungjawab

2. Pertentangan dengan atasan

3. Ketidaksesuaian tanggungjawab dengan wewenang

4. Pertentangan dengan rekan kerja.

5. Ketidaksesuaian tugas dengan prinsip individu.

1. Ketidakjelasan tujuan peran.

2. Ketidakjelasan pertanggungjawaban

3. Ketidakcukupan wewenang dengan tugas yang diberikan

4. Ketidakpahaman apa yang diharapkan

5. Ketidakpahaman peranan pekerjaan dalam mencapai tujuan

1. Kurangnya semangat kerja

2. Ketidaklancaran komunikasi

3. Kesalahan mengambil keputusan menurun, komunikasi tidak lancar, sering keliru dalam mngambil keputusan, tidak

4. Hilangnya kreativitas dan inovasi

5. Penurunan kesehatan kesehatan. 


\begin{tabular}{lll}
\hline \multicolumn{1}{c}{ Variabel } & \multicolumn{1}{c}{ Definisi Operasional } & \multicolumn{1}{c}{ Indikator } \\
\hline & & \\
& & \\
Kinerja & $\begin{array}{l}\text { Kinerja pegawai didefinisikan } \\
\text { sebagai kemampuan pegawai }\end{array}$ & 1. Ketepatan waktu dalam bekerja \\
& $\begin{array}{l}\text { 2. Ketelitian } \\
\text { dalam melakukan pekerjaan }\end{array}$ & 3. Target \\
& $\begin{array}{l}\text { yang mencakup ketelitian, } \\
\text { penyelesaian pekerjaan, }\end{array}$ & 4. Kerja sama \\
& ketepatan waktu dan & \\
kemampuan kerjasama. & \\
\hline
\end{tabular}

\section{HASIL DAN PEMBAHASAN \\ Deskripsi Penilaian Responden}

Berdasarkan pada tabel 2, rata-rata total penilaian responden terhadap konflik peran menunjukkan bahwa terdapat konflik peran yang cukup tinggi $(5,79)$. Konflik yang berkaitan dengan ketidaksesuaian tanggungjawab dengan wewenang dinilai paling menunjukkan kondisi di dinas PJPR. Sedangkan pertentangan dengan atasan maupun rekan kerja dinilai relatif lebih rendah.

Responden menilai ambiguitas peran yang terjadi di dinas PJPR tinggi namun lebih rendah dibanding konflik peran. Ketidakcukupan wewenang dalam melaksanakan tugas yang diberikan menjadi indikator paling tinggi. Sedangkan ketidakjelasan tujuan peran dinilai paling rendah terjadi.

Ditinjau dari rata-rata nilai stres, para pegawai Dinas PJPR indikasi stres sangat tinggi. Stres kerja yang paling banyak terjadi adalah penurunan kreativitas dan inovasi serta penurunan kesehatan, sedangkan ketidaklancaran komunikasi dinilai paling rendah. Sedangkan variabel kinerja dinilai mendekati sedang yaitu 5,21. Kondisi ini menjukkan kinerja para pegawai dinas PJPR cukup rendah. Ketepatan waktu penyelesaian pekerjaan dan ketelitian menjadi indikator yang dinilai paling rendah.

Tabel 2. Deskripsi Penilaian Responden Terhadap Variabel Penelitian dan Loading

\begin{tabular}{|c|c|c|c|c|}
\hline Variabel & Indikator & Rata-rata & Rata-rata total & Loading \\
\hline \multirow[t]{5}{*}{ Konplik peran } & $\begin{array}{l}\mathrm{X} 1: \text { Ketidaksesuaian tugas dengan } \\
\text { tanggungjawab }\end{array}$ & 6,04 & 5,79 & 0,82 \\
\hline & $\mathrm{X} 2$ : Pertentangan dengan atasan & 5,12 & & 0,80 \\
\hline & $\begin{array}{l}\text { X3: Ketidaksesuaian tanggungjawab } \\
\text { dengan wewenang }\end{array}$ & 6,58 & & 0,84 \\
\hline & X4: Pertentangan dengan rekan kerja & 5,24 & & 0,76 \\
\hline & $\begin{array}{l}\text { X5: Ketidaksesuaian tugas dengan prinsip } \\
\text { individu }\end{array}$ & 6,04 & & 0,85 \\
\hline \multirow{5}{*}{$\begin{array}{l}\text { Ambiguitas } \\
\text { peran }\end{array}$} & X6 : Ketidakjelasan tujuan peran & 5,64 & 5,62 & 0,76 \\
\hline & X7: Ketidakjelasan pertanggungjawaban & 5,70 & & 0,73 \\
\hline & $\begin{array}{l}\text { X8: Ketidakcukupan wewenang dengan } \\
\text { tugas yang diberikan }\end{array}$ & 5,93 & & 0,89 \\
\hline & $\begin{array}{l}\text { X9: Ketidakpahaman apa yang } \\
\text { diharapkan }\end{array}$ & 5,91 & & 0,83 \\
\hline & $\begin{array}{l}\text { X10: Ketidakpahaman peranan pekerjaan } \\
\text { dalam mencapai tujuan }\end{array}$ & 4,91 & & 0,94 \\
\hline
\end{tabular}




\begin{tabular}{|c|c|c|c|c|}
\hline \multirow[t]{5}{*}{ Stres kerja } & X11: Kurangnya semangat kerja & 6,35 & 6,31 & 0,81 \\
\hline & X12: Ketidaklancaran komunikasi & 6,05 & & 0,96 \\
\hline & X13: Kesalahan mengambil keputusan & 6,29 & & 0,90 \\
\hline & X14: Hilangnya kreativitas dan inovasi & 6,40 & & 0,94 \\
\hline & X15: Penurunan kesehatan & 6,37 & & 0,93 \\
\hline \multirow[t]{4}{*}{ Kinerja } & X16: Ketepatan waktu dalam bekerja & 5,14 & 5,21 & 0,83 \\
\hline & X17: Ketelitian & 5,14 & & 0,91 \\
\hline & X18: Target & 6,11 & & 0,98 \\
\hline & X19: Kerjasama & 5,45 & & 0,85 \\
\hline
\end{tabular}

\section{Model Hubungan Konflik Peran, Ambiguitas Peran, Stres Kerja Dan Kinerja}

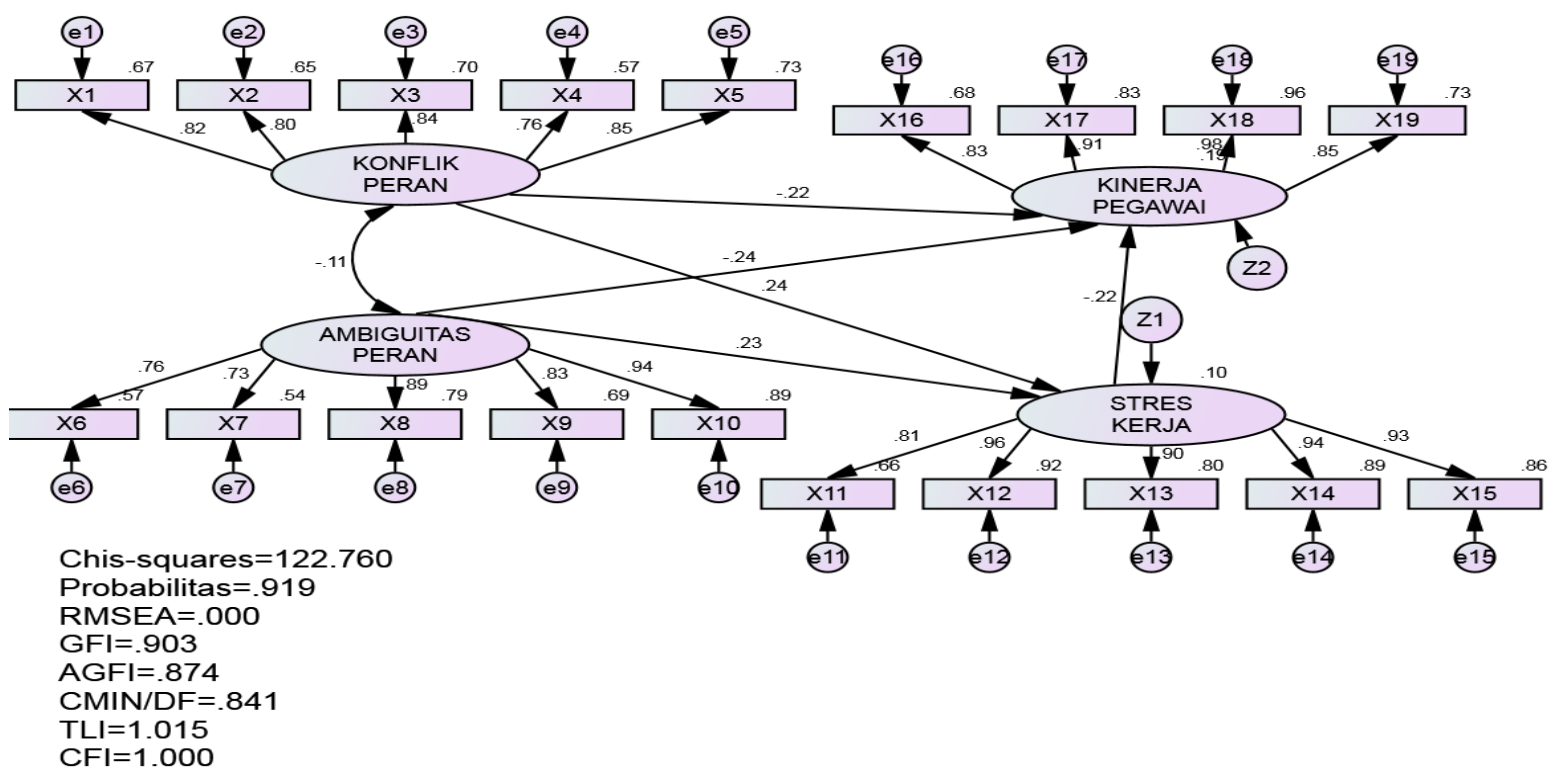

Gambar 1. Model Hubungan Konflik Peran, Ambiguitas Peran, Stres Kerja dan Kinerja

Tabel 3. Hasil Pengujian Kelayakan Model

\begin{tabular}{ccccc}
\hline No & Kriteria & Hasil Model Ini & Model Fit & Estimasi Model \\
\hline 1 & Chi Square & 122,760 & Diharapkan Kecil & Lebih kecil dari nilai DF sebesar 146 \\
2 & Probability & 0,919 & $\geq 0,05$ & Baik \\
3 & AGFI & 0,874 & $\geq 0,9$ & Marginal \\
4 & GFI & 0,903 & $\geq 0,9$ & Baik \\
5 & TLI & 1,015 & $\geq 0,95$ & Baik \\
6 & RMSEA & 0,000 & $\leq 0,08$ & Baik \\
7 & CMIN/DF & 0,841 & $\leq 2,00$ & Baik \\
8 & CFI & 1,000 & $\geq 0,95$ & Baik \\
\hline
\end{tabular}

\section{Uji Hipotesis}

Berdasarkan tabel 4., menunjukkan bahwa nilai probabilitas(p) seluruhnya lebih kecil dari 0,05, maka dapat disimpulkan hipotesis 1 sampai dengan hipotesis 5 terbukti. Konflik peran dan ambiguitas peran berpengaruh positif terhadap stres kerja. Konflik peran, Ambiguitas peran dan Stres kerja berpengaruh negatif terhadap kinerja pegawai. 
Agus Joko Triyono dan Agus Prayitno : Pengaruh Konflik Peran Dan Ambiguitas Peran Terhadap Stres Kerja Dan Kinerja Pegawai Dinas Penerangan Jalan Dan Pengelolaan Reklame Kota Semarang

Tabel 4. Hasil Pengujian Hipotesis

\begin{tabular}{lllccccc}
\multicolumn{1}{c}{ Var. Dependen } & & Var. Independen & Estimate & S.E. & C.R. & P & Hasil \\
\hline Stres_kerja & $<---$ & Konflik_peran & .236 & .132 & 2.380 & .017 & Terbukti \\
Stres_kerja & $<---$ & Ambiguitas_peran & .231 & .123 & 2.385 & .017 & Terbukti \\
Kinerja_pegawai & $<---$ & Stres_kerja & -.224 & .104 & -2.334 & .020 & Terbukti \\
Kinerja_pegawai & $<---$ & Ambiguitas_peran & -.240 & .132 & -2.510 & .012 & Terbukti \\
Kinerja_pegawai & $<---$ & Konflik_peran & -.225 & .142 & -2.285 & .022 & Terbukti \\
\hline
\end{tabular}

\section{PEMBAHASAN}

Berdasarkan nilai estimate pada tabel 4, konflik peran memiliki pengaruh positif terhadap stres kerja lebih besar daripada pengaruh ambiguitas peran, namun variabel ambiguitas peran memiliki pengaruh negatif paling besar terhadap kinerja. Stres kerja memiliki pengaruh negatif terhadap kinerja. Hasil ini menunjukkan bahwa baik konflik peran maupun ambiguitas peran memiliki peranan yang sama sama beresiko yang dapat menurunkan kinerja pegawai.

Konflik peran memiliki pengaruh negatif secara tidak langsung terhadap kinerja pegawai sedangkan ambiguitas peran memiliki pengaruh negatif secara langsung lebih besar. Indikator konflik peran yang memiliki loading paling tinggi adalah ketidaksesuaian tugas dengan prinsip individu. Menunjukkan bahwa konflik peran yang sering terjadi pada dinas PJPR adalah ketidaksesuaian tugas dengan prinsip individu disusul dengan ketidaksesuaian tanggungjawab dengan wewenang, serta ketidaksesuaian tugas dengan tanggungjawab. Sehingga untuk meningkatkan kinerja pegawai adalah dengan cara mengevaluasi dan menyusun deskripsi pekerjaan secara jelas sehingga ketidaksesuian tugas dengan tanggungjawab, maupun ketidaksesuaian tanggungjawab dan wewenang dapat di hilangkan.

Sejalan dengan penelitian yang dilakukan Usman, dkk (2011), Quarat-ul-ain, dkk (2012) dan Nurqamar, dkk (2014) yang menyimpulkan konflik peran berpengaruh positif terhadap stres kerja.

Hasil pengujian hipotesis menunjukkan bahwa ambiguitas peran berpengaruh positif dan signifikan terhadap stres kerja. Jika pegawai menilai bahwa tujuan peran tidak jelas, pertanggungjawaban tidak jelas, wewenang yang diberikan tidak mencukupi, harapan yang sulit dipahami dan diperparah dengan lemahnya pemahaman peran pekerjaan yang dilakukan memicu pegawai menjadi stres. Berdasarkan penilaian responden indikator ketidakcukupan wewenang merupakan indikator yang paling dirasakan para pegawai. Sedangkan ketidakpahaman peranan pekerjaan dalam mencapai tujuan tidak dinilai tinggi namun ditinjau dari nilai loading memiliki kontribusi paling besar pada terjadinya ambiguitas peran. Dinas PJPR perlu meninjau kembali wewenang setiap pegawai yang mampu mendukung penyelesaian tugas yang dibebankan. Sejalan dengan Usman dkk (2011) dan Quarat-ul-ain, dkk (2012) juga menyimpulkan bahwa ambiguitas peran yang meningkat mengakibatkan pegawai semakin stres.

Hasil pengujian menunjukkan bahwa stres kerja berpengaruh negatif dan signifikan terhadap kinerja pegawai. Meningkatnya stres kerja yang ditandai menurunnya semangat kerja, komunikasi yang tidak lancar, keputusan yang sering salah, menurunnya kreativitas pegawai dan kondisi kesehatan yang menurun akan mengakibatkan pekerjaan tidak tepat waktu, tidak teliti, target tidak tercapai dan kerjasama terhambat. Penuruna stres pegawai menjadi penting untuk meningkatkan kinerja pegawai. Penurunan stres dilakukan dengan penurunan konflik peran dengan memperjelas deskripsi tugas sehingga jelas pertanggungjawabannya serta penurunan ambiguitas peran dengan mempertajam wewenang yang diberikan. Sejalan dengan penelitian Saina (2013) yang bahwa stres kerja berpengaruh secara negatif terhadap kinerja pegawai. 


\section{SIMPULAN}

Kesimpulan penelitian ini adalah pertama : konflik peran dan ambiguitas peran memiliki pengaruh positif terhadap stres kerja dengan konflik peran memiliki pengaruh yang dominan. Kedua, Konflik peran memiliki pengaruh negatif terhadap kinerja melalui stres kerja lebih dominan dibandingkan ambiguitas peran, sedangkan ambiguitas peran memiliki pengaruh langsung lebih busar dibanding pengaruh konflik peran. Ketiga, kejelasan tugas, tanggungjawab dan wewenang seorang pegawai menjadi indikator paling penting dalam menurunkan stres dan meningkatkan kinerja pegawai.

\section{DAFTAR PUSTAKA}

Cahyono, Dwi. 2008. Persepsi ketidakpastian lingkungan, ambiguitas peran, dan konflik peran sebagai mediasi antara program mentoring dengan kepuasan kerja, prestasi kerja dan niat ingin pindah. Tesis . Semarang: Universitas Diponegoro.

Celik, K. 2013. The effect of role ambiguity and role conflict on performance of vice principals: the mediating role burnout, Eurasian Journal of Educational Research. Spring (51). 195-214.

Handoko, Hani. 2010. Manajemen Personalia \& Sumberdaya Manusia. Edisi kedua. Yogyakarta: BPFE UGM.

Ivancevich. et al. 2007. Perilaku dan Manajemen Organisasi. Edisi ketujuh. Jakarta: Erlangga.

Kirkcaldy, B. D., Levine, R., \& Shephard, R. J. 2000. The impact of working hours on physcal and psychological health of German managers. European. Review of Applied Psychology. 443-449.

Kreitner, Robert dan Angelo Kinicki. 2014. Organizational behavioral-Ed. 5. Boston: McGraw-Hill.

Luthans, Fred. 2011. Organizational Behavior : An Evidence - Based Approach. New York: McGraw-Hill.

Mangkunegara, AP. 2012. Manajemen Sumber Daya Manusia Perusahaan. Bandung : PT Remaja Rosdakarya.

Munandar A.S. 2008. Psikologi Industri dan Organisasi. Jakarta: Penerbit Universitas Indonesia (UI-Press).

Nimran, Umar. 2004. Perilaku Organisasi. Cetakan Ketiga. Surabaya: CV. Citra Media.

Nurqamar, Insany Fitri, Haerani S., Mardiana, R. 2014. Konflik peran dan Ambiguitas Peran : Implikasinya Terhadap Stres Kerja dan kinerja pejabat Struktural Prodi. Jurnal Analisis. 3(1): 24-31.

Patria R. 2016. Pengaruh konflik peran dan ambiguitas peran terhadap kinerja auditor dengan kecerdasan emosional sebagai variabel moderasi (studi empiris pada KAP di Pekanbaru Padang dan Batam). JOM Fekon. 3(1): 881-895.

Quarat-ul-ain, khattak \& Iqbal. 2013. Impact of role conflict on job satisfaction, mediating role of job stres in private banking secto. Interdisciplinary Journal Of Contemporary Research In Business. 4(2).

Rivai H.V. \& Mulyadi D. 2011. Kepemimpinan dan perilaku organisasi. Jakarta: Rajawali pers.

\& Sagala, E.J. 2009. Manajemen Sumber Daya Manusia Untuk Perusahaan Edisi 2. Jakarta: PT. Raja Grafindo.

Robbins, Stephen P. dan Timothy A. Judge. 2008. Perilaku Organisasi Edisi ke-12, Jakarta: Salemba Empat

Safaria, Ahmad dan Nubli. 2011. Role Ambiguity, Role Conflict, the Role of Job Insecurity as Mediator toward Job Stres among Malay Academic Staff: A SEM Analysis. Journal of Social Sciences. 3(3): 229-235. 
Agus Joko Triyono dan Agus Prayitno : Pengaruh Konflik Peran Dan Ambiguitas Peran Terhadap Stres Kerja

Dan Kinerja Pegawai Dinas Penerangan Jalan Dan Pengelolaan Reklame Kota Semarang

Saina Nur. 2013. Konflik, stres kerja dan kepuasan kerja pengaruhnya terhadap kinerja pegawai pada Universitas Khairun Ternate. Jurnal EMBA. 1(3): 739-749

Sinambela, Lijan. 2012. Kinerja Pegawai: Teori, Pengukuran dan Implikasi. Yogyakarta: Graha Ilmu.

Sutrisno, Edy. 2011. Budaya Organisasi. Jakarta: Kencana Prenada Media Group.

Usman, Ahmad. Zulfiqar A., Ishfaq A., \& Zeeshan A. 2011. Work Stres Experienced by the Teaching Staff of University of the Punjab, Pakistan Antecedents and Consequences. International Journal of Business and Social Science 2(8). 